\title{
Publisher Correction: Aggregation of poorly crystalline and amorphous components of infectious urinary stones is mediated by bacterial lipopolysaccharide
}

Jolanta Prywer \& Agnieszka Torzewska

Correction to: Scientific Reports https://doi.org/10.1038/s41598-019-53359-z, published online 19 November 2019

In the original PDF version of this Article, the Data Availability statement was obscured by the publication date. This has now been corrected in the PDF version of this Article.

In addition, there was a typographical error in the Results section under subheading 'Influence of LPS on the nucleation and growth of PCaAP',

"The interaction between LPS and precipitated PCaAP can take place by means of vander Waals forces or hydrogen bonds."

now reads:

"The interaction between LPS and precipitated PCaAP can take place by means of van der Waals forces or hydrogen bonds."

This has now been corrected in the HTML and PDF versions of this article.

(c) (i) Open Access This article is licensed under a Creative Commons Attribution 4.0 International License, which permits use, sharing, adaptation, distribution and reproduction in any medium or format, as long as you give appropriate credit to the original author(s) and the source, provide a link to the Creative Commons license, and indicate if changes were made. The images or other third party material in this article are included in the article's Creative Commons license, unless indicated otherwise in a credit line to the material. If material is not included in the article's Creative Commons license and your intended use is not permitted by statutory regulation or exceeds the permitted use, you will need to obtain permission directly from the copyright holder. To view a copy of this license, visit http://creativecommons.org/licenses/by/4.0/.

(c) The Author(s) 2020 